unpigmented areas is reversed, again indicating the greatest area of future development.

The Hoary Bat is a sclitary species which probably occurs uncommonly throughout most of the province, but particularly in the forested regions. Like other bats, it is believed to migrate south for the winter. Additional information concerning the distribution and habits of this and other species of bats is always welcomed. Bats may be shipped alive to the Museum in a perforated box, or dead bats may be sent preserved in alcohol.

\title{
Experiences With Orphan Fawns
}

\section{By Dave Santy, Beechy}

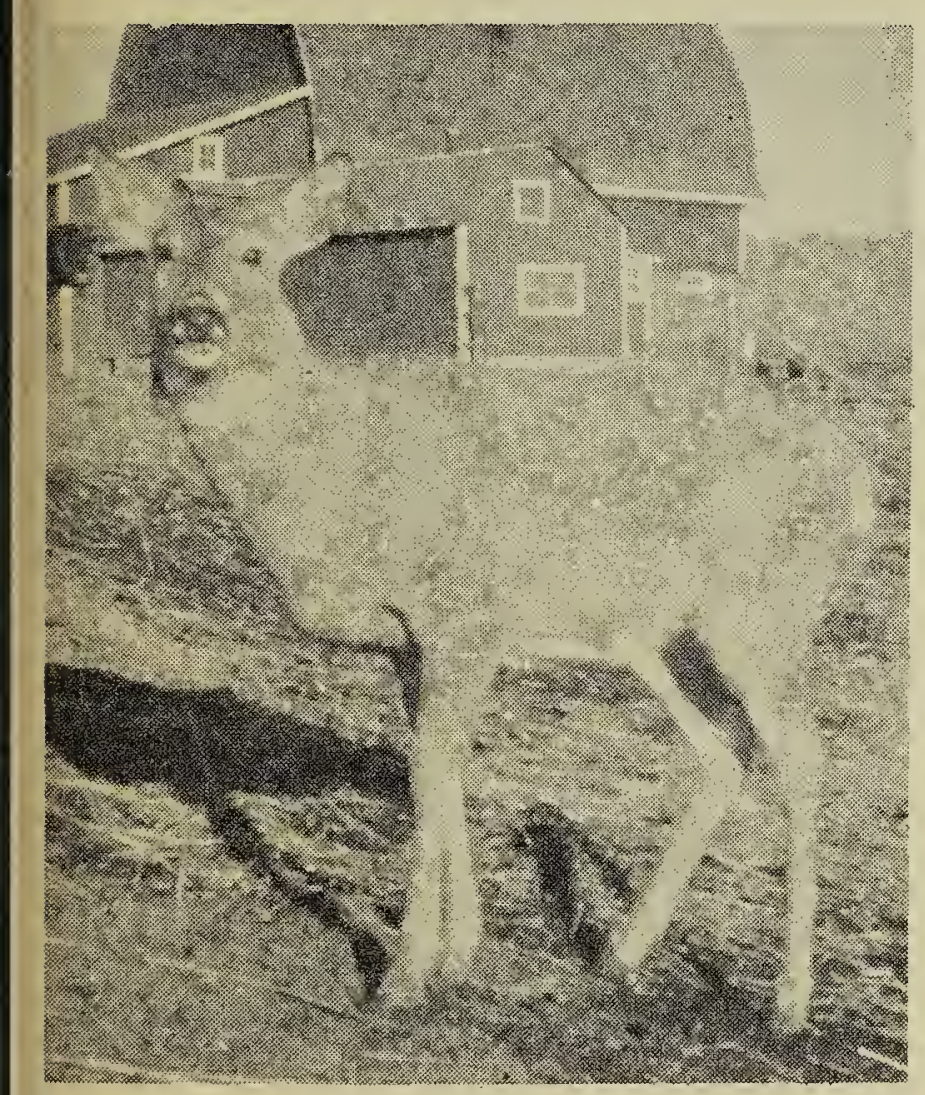

Picture by Dennis Treslan

The Galbraith deer at two years of age.

Mr. Jack Link, of Beechy, is a commuting farmer. Three years ago on a bright spring morning, he arrived at the farm, about eight miles south of Beechy, and saw a fawn stumbling weakly over a summerfallow field. He went toward the little fellow, who was in such a weakened condition that he showed no signs of alarm. Jack, satisfied that the fawn had strayed from its mother or that something had happened to the matron, lifted it into the truck cab and took it home. The family immediately went to work trying to give it nourishment and before long had the waif taking quite kindly to the baby bottle.

In a few days the fawn came to be decidedly demanding of attention. He was being housed in the grain box of the big truck, but since this would not hold him long the family had to give consideration to making proper disposition of him. They contacted the Game Branch at Regina. By favourable coincidence, the Branch had just received a request from $\mathrm{Mr}$. and Mrs. Nyholt of North Battleford for authority to try and get a young deer. The Department forthwith sent a letter of authority to those good folks to take possession of "Bambi". Nor did the Nyholts lose any time in doing so. They came to Beechy immediately.

Mr. and Mrs. Nyholt, at their Golden Gate Wildlife Farm, have various. forms of domesticated wildlife. These wild animals and their numerous ponies are a big attraction to their visitors.

In a letter from $\mathrm{Mr}$. and Mrs. Nyholt written to them last Christmas, Mr. and Mrs. Link learned that Bambi has grown to be a majestic specimen of deerhood and that he now has a suitable mate on which he lavishes every attention.

Almost simultaneously with $\mathrm{Mr}$. Link's finding the little fawn, $\mathrm{Mr}$. E. Bowman and his son-in-law Pat Galbraith, ranchers and farmers, were fixing fence in a field adjoining the Links' summerfallow and they too came across a young and very weak fawn. They left it there until they found a dead doe fresh in milk a short distance down the fence line. They considered it a family tragedy and Pat took the little fawn home. He responded well to the bottle feeding and kindly treatment of Mrs. Galbraith. It was not until months later that Mr. Link and Mr. Galbraith learned of the coincidence of their finds and concluded that the two fawns were of the same family. 
The Galbraiths' protégé also grew to be a full-antlered beauty. We knew him well. and it was with deep regret that we learned he had been found dead near his home last fall. For the past three years he had rambled about the neighbourhood freely and he had come to know the folks who gave him a handout. He always recognized the Galbraith farm as his home and returned there regularly or when he was agitated, probably after being chased.

One of his favourite recreational stunts was to suddenly leave the cattle with whom he fraternized and race for home, clearing the yard fence, to chase the barnyard forwl at full speed and send them helter-skelter. Then he would leap over the fence again and go back to the leisurely, sedate company of the cows. He never caused a casualty among the chickens.

In death he showed signs of having been in a conflict, possibly with one of his own kind. A horn was broken off at the base and his head was badly festered. The slough where he died was his favourite watering and resting place and he may, in a weakened condition, have endeavoured to reach the receding waters and got bogged down in the mud.

\section{DEER MAKES A SUICIDE JUMP OFF NIPAWIN BRIDGE}

On June 22, 1958, it was reported to me that a male deer was killed instantly when jumping off the $\mathrm{Ni}$ pawin traffic bridge. Mr. Ostberg, of Ostberg Equipment, witnessed the proceedings along with another person whose name is not known at the present time.

When Mr. Ostberg approached the bridge from the north with his vehicle he observed the deer running on the bridge ahead of the car. At this moment another car approached the bridge from the south entrance causing the deer to jump clear of the on-coming traffic. Mr. Ostberg states that the deer died instantly when hitting the water and was last seen drifting downstream.

That is something that seldom occurs to wildlife, and I thought it would be of some interest to you.
-G. J. Pederson, Cons. Officer Dept of Nat. Resources, Nipawir Sask.

\section{INGENIOUS FOX}

Over 60 years ago I was workin on Mrs. Jchn Young's ranch, nea the present town of Kamsack. On day, Mr. Young saw a fox amons his sheep in the yard. Nearby there was an unused chicken hous with a hole in the roof. The for entered the chicken house and $\mathrm{Mr}$ Young picked up a stick and ran ir after it. He thought he had that fo cornered and tried his hardest to hit the animal with his stick, bu each time he brought the stick dow Mr. Fox was just not there. Th fox took in the situation and notice that Mr. Young was standing jus beneath the hole in the roof. $H$ jumped up on Mr. Young's bacl and hopped out of the hole and away! Who says that wild animal don't think when met with a nev situation.-P. Fraser, Kelvington Sask.

\section{BARKING TIMBER WOLF}

Have you ever heard a timbe: wolf bark? I heard one on an Oc tober evening last year. I was stand ing in my rowboat deep in a creek On my right was a wooded hill, or my left a small rocky island with : dense bush, and before me oper sandbanks. A pack of young timbe wolves were howling in the hill and coming in my direction. Wher they reached the woods above the sandibanks they stopped, so near to me that I could recognize individua voices in the chorus. In the fading light, I saw quick movements at the far end of the sand, and a shadow seemed to cross the banks opposite me and disappear in the bush or the small island. Shortly after that a single wolf howled in the bust and at once the sand of the bank: was alive with the black bodies a young wolves running. I shot in the middle of the running pack. They separated at once; some reached the island and the rest turned back to the woods. Directly opposite me ir the bush a wolf howled, and ther I was surprised to hear the how: change into an angry snarl and bark. like that of a very angry dog. He was still barking as I rowed away -A. Baltz, Prince Rupert, B.C. 